\title{
EFFECT OF SERVICE QUALITY AND FACILITIES ON COMMUTERLINE TRAIN USER SATISFACTION: A CASE OF INDONESIA
}

\author{
*Aswanti Setyawati ${ }^{1}$, Husni Hasan ${ }^{2}$ \\ ${ }^{1,2}$ Institut Transportasi dan Logistik Trisakti \\ *Coresponding author. \\ E-mail addresses: aswantimurgiyanto@gmail.com
}

\begin{abstract}
ARTICLE INFO
Article history:

Received:

21 August 2021

Accepted:

15 October 2021

Available online:

26 November 2021

ABSTRACT

The effect of service quality and facilities on user satisfaction of JABODETABEK Commuter Line Train. The purpose of this study was to see how the influence of service quality and facilities on user satisfaction of Jabodetabek commuter line trains. The method used in this research is quantitative research which is descriptive and verification in nature. Data collection techniques using questionnaires, observation and literature study. While the data analysis method used in this research is validity test, reliability test, path analysis, $t$ test and F test using SPSS.23.0. The sampling technique used was non-probability sampling, purposive sampling type. The number of users sampled is a population of 336,045 passengers with a $5 \% \mathrm{MOE}$ at a $95 \%$ confidence level based on the Isaac \& Michael formula is $\mathrm{S}=348$ samples. According to analysis carried out it can be concluded quality of service effect amounted to $38.00 \%$ on user satisfaction Commuter Line, influential facilities for $40.30 \%$ of the Commuter Line user satisfaction and jointly quality of service and facility has an influence of $78.30 \%$ on Commuter Line Train user satisfaction. Based on the results of this study, the steps that need to be taken by the management of PT. KAI is to make efforts to further improve the quality of Commuter Line Train user satisfaction through improving the quality of service (Service Quality) and facilities (Facility / infrastructure).
\end{abstract}

Keyword: Commuter Line, Service Quality, Facility, Customer Satisfaction.

\section{INTRODUCTION}

The land transportation services industry is a very large and growing transportation industry. This growth was not only caused by the increase in land transportation service users, both for the purpose of traveling people and for transporting goods. The Commuter Line Electric Rail Train (KRL) is a mode of public transportation with a large carrying capacity for the people of Jakarta and its surroundings. Since 19 September 2017, PT KAI Commuter Jabodetabek has changed its name to PT Kereta Commuter Indonesia, which is one of the subsidiaries within PT Kereta Api Indonesia (KAI) which manages the Jabodetabek Commuter Train and its surroundings. KAI was formed in accordance with Presidential Instruction No. 5 of 2008 and the Letter of the Minister of State for SOEs No. S-653 / MBU / 2008 dated August 12, 2008. The main task of this new company is to provide commuter rail transportation services using the Electric Rail Train in the Jakarta, Bogor, Depok, Tangerang, and Bekasi (Jabodetabek) and surrounding areas as well as business in the non-passenger 
transportation business sector. KAI started the modernization of KRL transportation in 2011 by simplifying the existing routes into five main routes, eliminating express KRL, implementing women-only trains, and changing the name of the AC-economy KRL to Commuter Line trains. This project is followed by renovation, rearrangement, and sterilization of facilities and infrastructure including train lines and train stations carried out together with PT KAI (and the Government. As of December 2019, KAI already has 1,100 KRL units, and the number will continue to grow. Throughout 2019, KCI has added a fleet of 168 units. This is to meet the increasing demand for passengers from time to time. During 2019, the number of KRL users reached 336,045 passengers or PT KAI per day on average serving 28,004 passengers from all over Jabodetabek. As a facility operator, the Commuter Line train operated by KAI currently serves 80 stations throughout Jabodetabek, Banten and Cikarang with a route range of $418.5 \mathrm{~km}$.

In line with the increasing number of Electric Rail Train (KRL) users, this results in a decrease in the level of consumer satisfaction. The phenomenon of decreasing customer satisfaction should be the main concern of service companies because these two factors determine the company's performance. The factors that simultaneously influence customer satisfaction and loyalty are consumer perceptions of service quality and relationship quality. This can be seen from the results of several studies that service quality and relationship quality are significant factors in increasing customer satisfaction (Segoro 2013).

According to a survey by republika.co.id in 2014, there were five passenger complaints that were felt to be very important for improvement by the management of PT KAI Jabodetabek, including the first AC facility where the air conditioner often does not function when the carriage is full. The second is the carriage lights, this is related to the lights in a number of carriages that often turn off. The third is a complaint against KAI's facilities related to the frequent shutdown of the station notification sound system. And the last one is the KRL Fleet so that passengers are jostling so that the waiting time for passengers is getting longer. The results of this satisfaction survey attracted the attention of researchers to further develop research on KRL passenger satisfaction with the facilities provided by the PT KAI Commuter Line Jabodetabek. As a first step, the researchers conducted a pre-survey of 50 random passengers using an open questionnaire. The open question posed by the researcher is "in your opinion what facilities need to be repaired for the convenience of your trip using KRL". The highest answer is AC facilities with a score of 20 respondents, carriage lights with 15 respondents, sound system with 5 respondents and finally the KRL fleet facilities which are not proportional to the current number of KRL passengers as many as 10 respondents. The results of this pre-survey research confirm the results of a survey conducted by Republika.co.id regarding the satisfaction of Jabodetabek Commuter Line KRL users, resulting in a gap between increasing users and a number of facilities provided by PT KAI in the operation of the Jabodetabek KRL. The following is data from the pre-survey results with an increase in the number of passengers from 2015 to 2019.
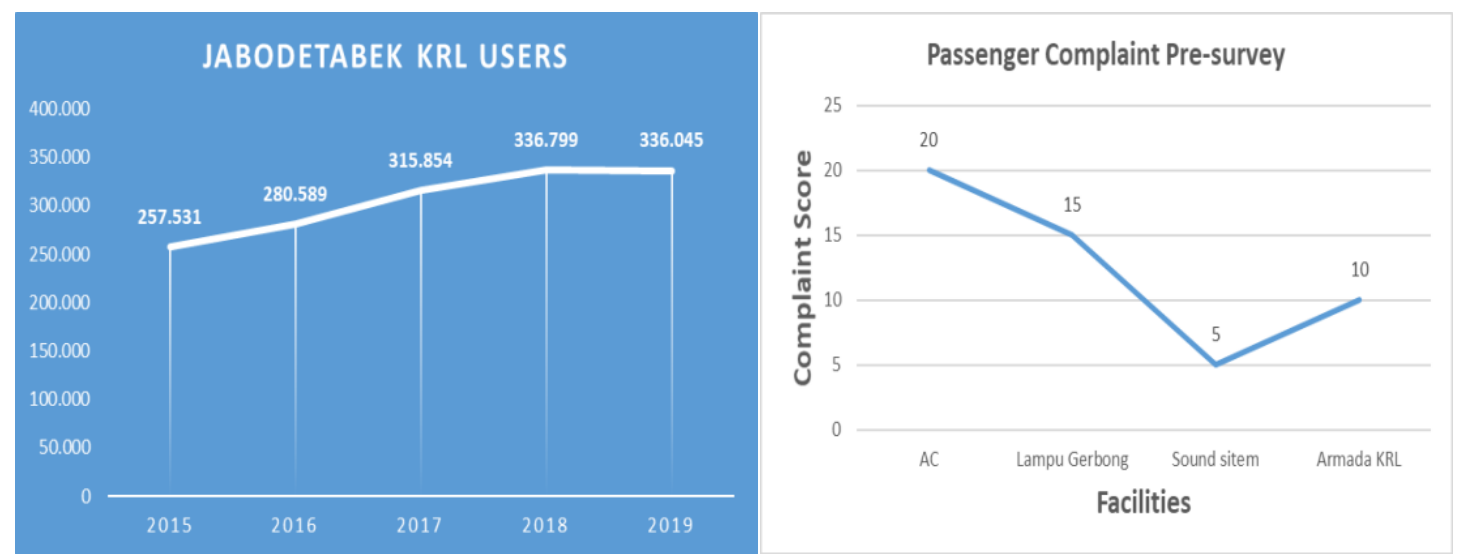

Figure 1. Research gap data

Source: KAI \& Pre-Survey (2021) 
The increasing trend of Jabodetabek Commuter Line KAI users from 2015 to 2019 has not been accompanied by the provision of adequate KRL facilities, so that it has raised dissatisfaction with KRL users perpendicularly. This can be seen from the data on the increasing trend of users with the data from the presurvey results of the Commuter Line KRL users. Understanding customer expectations regarding organizational social responsibility is fundamental to creating and implementing successful service strategies and programs so that customer satisfaction levels will be achieved (Santos et al., 2020). Many factors can influence satisfaction specifically that several studies assessing the relationship between service quality and satisfaction yield a consistent one. Service aspects as measured by availability, accessibility, diversity, relevance, and effectiveness produce mixed research results where the accessibility factor is a very strong factor in shaping customer satisfaction (Kassem et al., 2021). The level of customer satisfaction can also be built by the dimensions of service quality factors such as tangibility, reliability, responsiveness, assurance and empathy which are directly related to the level of customer satisfaction (Pahala et al., 2021). To determine the index of decreasing dissatisfaction and index of increasing satisfaction can be measured separately in order to overcome customer inequality to get customer preferences and desires. so that we can find out how different elements of service quality affect customer satisfaction (Shokouhyar et al., 2020). The phenomenon of decreasing customer satisfaction and loyalty should be the main concern of service companies because these two factors determine the company's performance.

With an increase in good service quality, it can lead to user loyalty, and the possibility of increasing new users. A loyal commuter line user means that the consumer feels satisfied and has done so more than once. This is very beneficial for the company, because through satisfying consumer needs, users will not glance at other modes of transportation and in the loyalty process, it is likely that free promotions in the form of word of mouth carried out by commuter line users are loyal to users of other modes of transportation (Shokouhyar et al., 2020). Public attitude towards public transportation services will be very important to increase demand for these services. Several important factors in predicting passenger satisfaction are security, safety and comfort, quality of infrastructure, and facilities (Saw et al., 2020). The number of visitors or the number of customers does not necessarily indicate customer satisfaction with the company where in addition to adequate service, the quality of the facilities provided by the company can also affect customer satisfaction (Wang et al., 2018)

In classifying public responses to types of public transportation, it can be seen that KRL is the only type of public transportation that has more negative sentiments than positive ones. On average, KRL is a type of public transportation with the lowest average sentiment value of -0.28 , then TJ of 0.1 , MRT of 0.11 , and LRT of 0.14 more often get negative sentiment from society than others. The activity of classifying this response can then be carried out periodically in a shorter time so that it can become an evaluation of the company to improve services (Rachman et al. 2021). Today's Commuter Line users are increasingly critical in assessing a quality of service, this is due to the increasing level of awareness of the right to get the best possible facilities and services this awareness is very high in the scope of service using trains. Therefore, to find out whether customer satisfaction has been fulfilled properly or not, it is necessary to conduct a direct survey of users of the Commuter Line service. To meet the demands of customers so that customers feel safe and comfortable and can fulfill their needs while waiting, the station also has supporting facilities that consumers can enjoy directly so that they don't feel bored while waiting (Mansur et al., 2021). Adequate and sufficient facilities provided by KAI are expected to provide satisfaction for customers. Therefore, the objectives of this study are twofold: (1) to determine the effect of service quality on overall satisfaction in using the JABODETABEK commuter line train (2) to determine the effect of perceived facilities on overall user satisfaction. 


\section{LITERATURE REVIEW}

\section{Customer Satisfaction}

Satisfaction is a way of evaluating quality. A very high level of customer satisfaction is believed to be the best indicator of the company's future profits. Satisfaction can be broadly characterized as an evaluation of the quality of a post-purchase product given pre-purchase expectations (Tse et al, 1990). Satisfaction as a customer's attitude towards meeting their needs. Satisfaction can also be defined as the feeling of pleasure or disappointment a person experiences after comparing the perceived performance or results of a product with his expectations (Angelova \& Zekiri, 2011). Customer satisfaction is a level where the needs, wants and expectations of customers can be met which will result in repeated purchases or continued loyalty so that customer satisfaction or dissatisfaction is an after-purchase assessment where the performance of the product purchased meets customer expectations (Rita et al., 2019). Satisfaction is a feeling of pleasure or disappointment for someone who appears after comparing the performance (result) of the product thought against the expected performance (or outcome). If the performance is below expectations then the customer is dissatisfied. If the performance meets expectations, the customer is satisfied. If performance exceeds expectations, the customer is very satisfied. Consumer satisfaction is a situation shown by consumers when they realize that their needs and wants are as expected and are met properly (Permana et al., 2021)

\section{Service quality}

Service is a strategy or key in various businesses or activities of a service nature, to achieve market competition, quality improvement and other forms of service is a very urgent matter by utilizing available technology, so that it becomes a continuous and integrated service. When defining the concept of service quality, one should always start with the customer, as quality is the most important factor for customers and also the basis of their opinion, which then results in the fact that service quality is achieved if customer expectations are met. One service quality approach that is widely used as a reference in research research is the SERVQUAL (model Service Quality). According to Parasuraman (2010), SERVQUAL (Service Quality) is based on the theory of disconfirmation of expectations and depends on the gap between customer expectations about services provided and evaluation of perceptions of services. Goetsch and Davis define Service Quality as a dynamic condition related to products, services, people, processes, and the environment that meet or exceed expectations. Service quality has a long-term effect in shaping customer satisfaction and will make customers loyal to the company (Chang \& Yeh 2017). Service quality can be measured by dimensions such as tangibility, reliability, responsiveness, assurance and empathy in which the high quality of service in that dimension will increase customer satisfaction. Service quality is the whole process of meeting customer needs so that customers feel valued by service staff, accurate billing, getting customer feedback from experience, and maintaining service speed during busy times. Important factors in service quality such as important environment \& facilities, safety \& security, mode of transportation and travel information, accessibility \& directions, comfort, convenience \& environmental quality 'and staff \& ticket management, are factors that become benchmarks in improve service quality (Chauhan et al., 2021).

\section{Amenities}

An equally important factor to consider after service in a service business is about facilities. In a service business, customers' assessment of a company is based on what they get after using the service. Facilities are tools used to simplify and facilitate a business or job. Facilities can also be interpreted as anything that can smooth or facilitate the implementation of a business. Another opinion says that a facility is something that makes it easy and smoothes a business, usually in the form of things or money. Measuring passenger satisfaction with public transport services is very important in both research and transportation practice (Ranaweera \& Prabhu, 2003). To improve infrastructure, facilities, services and public transport needs, transportation agencies need to understand how much passenger expectations have actually been fulfilled. Customer surveys are a must because they provide transit agents with valuable information such as which aspects are very important to passengers and what makes them particularly satisfied and dissatisfied (Le-Klähn 
et al. 2014; Lai \& Chen, 2011). According to Philp. Kotler(2001) defines facilities, namely everything that is physical equipment and is provided by the service seller to support consumer convenience. It can be said that from another point of view a facility is a means to facilitate the implementation of its function. Meaning that facilities are convenience. Facilities are anything in the form of objects or money that are used to facilitate and expedite an undertaking.

\section{Customer Service and Satisfaction}

Service quality is a significant factor affecting customer satisfaction (Li et al., 2021). In the concept of customer satisfaction, a good work environment and service-related training can create a positive service climate for employees, which in turn can increase customer satisfaction (Son et al., 2021). The strategy of increasing satisfaction does not depend solely on the criteria with the lowest level of satisfaction and weighted estimates, the nature of each criterion, the nature of customer demand, and the technical margin for customer service improvement. Service excellence is a strategic priority and that service significantly influences superior value creation, customer satisfaction, competitive advantage, growth, and profitability (Eren et al., 2013). The relationship between service personal values (SPV) and emotional satisfaction (E-SAC) is due to the customer service experience (Mustaffa et al., 2016). As consumers become more informed and more demanding about their purchasing services, failure to satisfy all consumers is inevitable. As a result, it is important to reduce consumer dissatisfaction caused by service failure factors (Jung \& Seock 2017). Service quality is one of the best measurement models of customer expectations and perceptions. Company performance results in customer satisfaction with products or services (Agarwal \& Gowda 2020)The determining factor for overall customer satisfaction and encouraging increased collaboration and coordination between various customers is on-demand services (Xu 2021)

\section{Facilities and Customer Satisfaction}

Commercial facilities or public facilities, such as those scattered at subway stations or business centers, can help identify problems in commercial facility services to improve the quality of life for urban residents, increase the number of network users and user satisfaction (Wang et al. 2018). Service quality performance (SQPM) is built to limit the facilities that need to be improved and those that may be maintained, which will increase the User Satisfaction Index (USI) which is based on the Customer Satisfaction Index (Ghosh et al., 2011). To increase customer satisfaction, factors such as communication skills, staff professionalism, service efficiency, product quality, scheduling, quantity of users (visitors) and service facilities are factors that need to be considered in future improvements. There are six attributes of servicescape, such as cleanliness, entertainment, and functionality, which have a positive effect on the perceived servicescape. In turn, it is felt that servicescape has a positive effect on emotional responses and customer satisfaction (Chen et al., 2009). Quantitative changes in the use of server facilities are correlated with customer satisfaction where the size and variety of quality facilities are increased to include more customers, will result in increased customer satisfaction but on the otherwise the firm's additional revenue will eventually decrease. Improve existing bus stops by adding facilities such as shelters, benches, sidewalks, etc. It is relatively cheap and popular with local officials and transport drivers, where this will increase passengers to use the facility so that the level of satisfaction will increase (Kim et al., 2020). The willingness of customers to pay is influenced by the provision of luxury branded room facilities. When luxury facilities such as Wi-Fi, and telephones are placed in the room, customer estimates about room rates and their willingness to pay both increase, this facility can be used to measure customer satisfaction with the products we put out. Based on the explanation above about the flow of thought between research variables by referring to the results of previous research and expert opinion, it can be described through a research model framework as shown in the following Figure: 


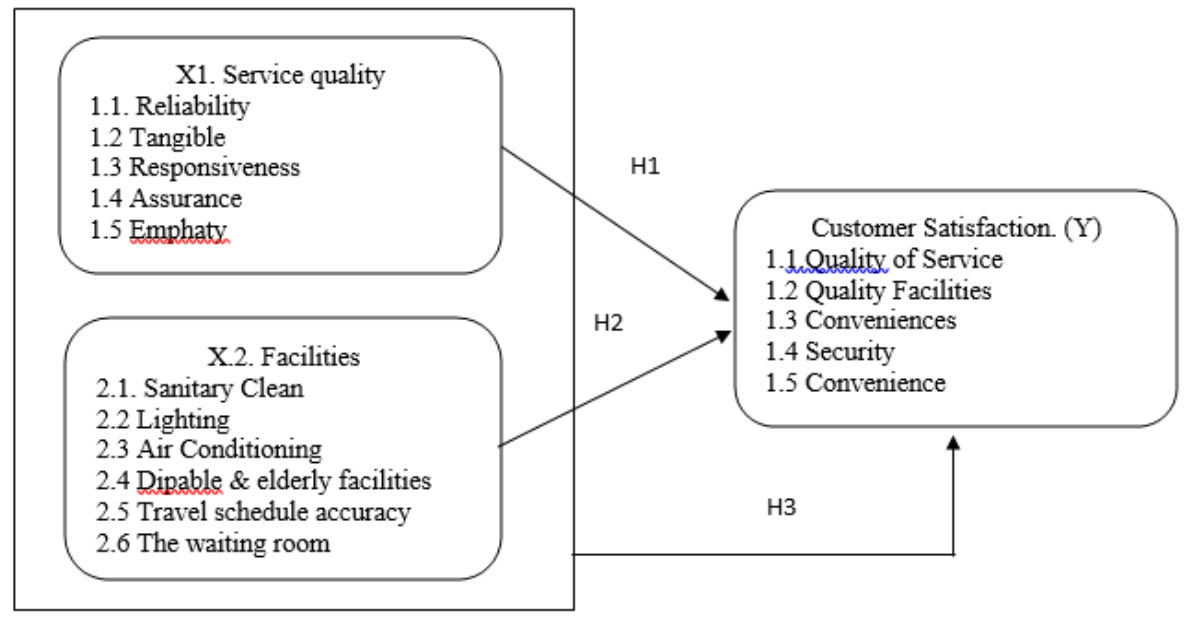

Figure 2. Concetual Framework

Source: Data processed by researchers (2021)

\section{Research Hypothesis}

Based on the research objectives, the hypothesis of this study is:

H1: Service has a significant effect on customer satisfaction of Commuter Line trains.

H2: Facilities have a significant effect on customer satisfaction of Commuter Line trains.

H3: Services and facilities have a significant effect on customer satisfaction of Commuter Line trains.

\section{METHODS}

Research was conducted by observing train passengers or commuter lines for the Jakarta Bogor, Jakarta Tangerang, and Jakarta - Bekasi routes. The number of samples from a total population of 336,045 passengers with a $5 \% \mathrm{MOE}$ at a $95 \%$ confidence level based on the Isaac \& Michael formula is S $=348$ samples. Validity and reliability tests were computerized using SPSS 23.0. In conducting the validity test the researcher is based on the theory that a question item is called valid if it meets the following requirements:

1) If the value of $r$ count is positive and $r$ counts $>r$ table, then the questionnaire item is declared valid

2) If the valu. e of $r$ count is negative or $r$ count $<r$ table, then the questionnaire item is declared

Invalid. Meanwhile, Reliability is the level of reliability of the questionnaire. A reliable instrument is an instrument that when used several times to measure the same object will produce the same dataA construct or variable is said to be reliable if it gives a cronbach alpha $(\alpha)$ value $>0.60$ and it is said to be unreliable if it gives a cronbach alpha $(\alpha)$ value $<0.60$. In addition to testing the validity and reliability of the research instrument, the researchers conducted several classical assumption test which includes normality test, multicollinearity test, and heteroscedasticity test where the purpose of this test is to determine whether there is a violation of classical assumptions as the basis for testing multiple linear regression before testing the hypothesis.

\section{FINDINGS AND DISCUSSION}

\section{Test Results of Validity and Reliability of Service Variables (X1), Facilities (X2) and Customer Satisfaction Variables (Y)}

The service variable research questionnaire $\left(\mathrm{X}_{1}\right)$ consisted of 7 questions consisting of $\mathrm{X} 1.1, \mathrm{X} 1.2, \mathrm{X} 1.3$, $\mathrm{X} 1.4, \mathrm{X} 1.5, \mathrm{X} 1.6$ and X1.7. The results of the calculation of the correlation score, then for questions X1.6 and X1.7 do not meet the validity requirements because $r$ count $>\mathrm{r}$. table. As for variables such as X1.1 has a value of $0.548>0.315, \mathrm{X} 1.2$ has a score of $0.586>0.315, \mathrm{X} 1.3$ has a score of $0.609>0.315, \mathrm{X} 1.4$ has a $\mathrm{t}-$ value of $0.698>0.315$ and $\mathrm{X} 1.5$ has a $\mathrm{t}$-value of $0.78>0.315$. Thus the items have met the validity requirements so that they can be included in the next test. For the Facility variable (X2) it is measured by 6 
measuring instruments such as X2.1, X2.2, X2.3, X2.4, X2.5 and X2.6. These items indicate that the calculation results meet the validity requirements where item $\mathrm{X} 2.1$ is $0.613>0.315$, item $\mathrm{X} 2.2$ is $0.687>$ 0.315 , item X2.3 is $0.602>0.315$, item X2.4 is $0.627>0.315$, item X2 .5 which is $0.728>0.315$, item X2.6 is $0.762>0.315$. Because all items meet the validity requirements, it can be concluded that the six measuring instruments can be included in further testing. The results of the validity test of the Customer Satisfaction variable $(\mathrm{Y})$ which consists of five question items consisting of Y1.1, Y1.2, Y1.3, Y1.4, Y1.5 All items are declared to meet the validity requirements because the value of $r$ - count $>r$ - table. This can be seen from the value of $\mathrm{r}$ - count $\mathrm{Y} 1.1$ which is $0.630>0.315$, item Y1.2 is $0.583>0.315$, item Y1.3 is $0.609>0.315$, item Y1.4 is $0.735>0.315$, and item Y1.5 is $0.752>0.315$. Thus all measuring instruments meet the validity requirements, hence the reliability test is carried out. Based on the results of reliability testing, it is known that the number of cronbach alpha is $0.735(\mathrm{Y}), 0.755$ variables $\left(\mathrm{X}_{1}\right)$, and $0.839\left(\mathrm{X}_{2}\right)$ which indicates that the alpha value is greater than the minimum value of cronbach alpha 0.6. Therefore, the value of the research instrument to measure the value of service variables $\left(\mathrm{X}_{1}\right)$, facilities $\left(\mathrm{X}_{2}\right)$ and customer satisfaction $(\mathrm{Y})$ can be said to be reliable.

\section{Classical Assumption Test Results Normality}

The normality test aims to test whether the dependent variable and the independent variable both have a normal distribution or not. A good regression model is data that is normally distributed or close to normal. The data normality test was carried out using the one-sample Kolmogorov-Mirnov Test, if the probability of asymp.sig $\alpha>0.05$, the research data was normally distributed.

Tabel 1. The Results of the One-Sample Kolmogorov-Smirnov Test Normality

\begin{tabular}{lll}
\hline & & Unstandardized Residual \\
\hline $\mathrm{N}$ & & 100 \\
Normal Parametersa,b & Mean & $0 \mathrm{E}-7$ \\
Std. Deviation & & .65140925 \\
Most Extreme & Absolute & .139 \\
Differences & & .105 \\
& Positive & -.139 \\
Negative & & 1.591 \\
Kolmogorov-Smirnov & $\mathrm{Z}$ & .620 \\
Asymp. Sig. (2-tailed) & & \\
\hline
\end{tabular}

a. Test distribution is Normal.

b. Calculated from data.

Source: Data processed by researchers (2021)

From table 1, it can be seen that the asymp.sig (2-tailed) value is $0.620>0.05$. So these results can be stated that the data used in this study have been normally distributed, because the significance value of the normality test for each variable is greater than $\alpha(\alpha=0.05)$, namely $0.620>0.05$.

\section{Multicollinearity.}

Symptoms of multicollinearity are characterized by a strong relationship between the independent (free) variables in a regression equation. If in a regression equation there are multicollinearity symptoms, it will cause estimation uncertainty, so that the conclusions drawn are not correct. A regression model that is declared free of multicollinearity if the value of $\mathrm{T}>0,10$ and $\mathrm{VIF}<10$. The results of the multicollinearity assumption test for this research variable can be seen based on the VIF value as follow 
Table 2. Coefficientsa Multicollinearity Test Results

\begin{tabular}{lllllllll}
\hline Model & \multicolumn{2}{l}{$\begin{array}{l}\text { Unstandardized } \\
\text { Coefficients }\end{array}$} & $\begin{array}{l}\text { Standardized } \\
\text { Coefficients }\end{array}$ & & Sig. & $\begin{array}{l}\text { Collinearity } \\
\text { Statistics }\end{array}$ \\
\cline { 2 - 5 } & $\mathrm{B}$ & $\begin{array}{l}\text { Std. } \\
\text { Error }\end{array}$ & Beta & & & $\begin{array}{l}\text { Tolera VIF } \\
\text { nce }\end{array}$ \\
\hline (Constant) & 2.114 & .810 & & 2.978 & .004 & & \\
\hline SERVICE & .601 & .145 & .162 & 1.225 & .225 & .632 & 1.620 \\
\hline AMENITIES & .645 & .173 & .160 & 1.208 & .231 & .632 & 1.620 \\
\hline
\end{tabular}

a. Dependent Variable: CUSTOMER SATISFACTION

Source: Data processed by researchers (2021)

From the table 2, it can be seen that the Tolerance value is $0.632>0,10$, and the VIF value is $1.620<10$. So it can be concluded that there is no multicollinearity.

\section{Heteroscedasticity}

Thetest is a test to determine whether the operating variables have the same (homogeneous) variance. To detect the presence of Heteroscedasticity symptoms, the Glejser test will be used. This method is done by regressing the independent variables to the residual absolute value. The regression model does not contain heteroscedasticity if the significant value of the independent variable on the absolute value of the statistical residual is above $\alpha>0.05$.

Table 3. Heteroscedasticity Test

\begin{tabular}{llllll}
\hline Model & \multicolumn{2}{l}{$\begin{array}{l}\text { Unstandardized } \\
\text { Coefficients }\end{array}$} & $\begin{array}{l}\text { Standardized } \\
\text { Coefficients }\end{array}$ & T & Sig. \\
\cline { 2 - 4 } & $\mathrm{B}$ & Std. Error & Beta & \\
\hline (Constant) & .985 & .436 & & 2.173 & .076 \\
\hline SERVICE & -.114 & .102 & -.196 & -1.480 & .382 \\
\hline AMENITIES & .057 & .138 & .036 & .423 & .858 \\
\hline
\end{tabular}

a. Dependent Variable: RES2

Source: Data processed by researchers (2021)

In table 3 it can be seen that the significance value of the two independent variables of service is 0.382 and facilities is 0.858 , meaning $>0.05$. Thus it can be concluded that there is no heteroscedasticity symptom in this study, a good regression model is a regression model that does not occur heteroscedasticity.

\section{Autocorrelation}

The autocorrelation test aims to test whether in the linear regression model there is a correlation between the confounding error in period $t$ and the confounding error in period t-1 (previous). Autocorrelation arises because consecutive observations throughout the year are related to one another series. To determine the presence of autocorrelation, the Durbin Watson test is used. Decision making with the Durbin Watson test is carried out by looking at the DW value between -2 to 2 , meaning that there is no autocorrelation or free autocorrelation. In this study, to test the autocorrelation, consider the following table:

Table 4. Auto Korelasi test

Model Summaryb

\begin{tabular}{llllll}
\hline Model & $\mathrm{R}$ & $\mathrm{R}$ Square & $\begin{array}{l}\text { Adjusted R } \\
\text { Square }\end{array}$ & $\begin{array}{l}\text { Std. Error of } \\
\text { the Estimate }\end{array}$ & $\begin{array}{l}\text { Durbin- } \\
\text { Watson }\end{array}$ \\
\hline 1 & $.382^{\mathrm{a}}$ & .173 & .098 & .9068 & 1.895 \\
\hline
\end{tabular}

a. Predictors: (Constant), AMENITIES _ SERVICE 


\section{b. Dependent Variable: SAISFACTION_SERVICE}

Source: Data processed by researchers (2021)

From the output results above, thevalue DW generated from the regression model is 1,895 . Because the DW value $(1,895)$ is in the area between DW between -2 to 2 , the Durbin Watson test decision making is done by looking at the DW value between -2 to 2 which means there is no autocorrelation or autocorrelation free.

\section{Multiple Linear Regression Test Results}

In this study, the data obtained will be processed with multiple linear regression models. The regression method can be used to show how the independent variable affects the dependent variable. The following table will show the results of the calculations for regression analysis.

Table 5. Multiple Linear Regression Test Results

Coefficients $^{\text {a }}$

\begin{tabular}{llllll}
\hline Model & \multicolumn{2}{l}{$\begin{array}{l}\text { Unstandardized } \\
\text { Coefficients }\end{array}$} & $\begin{array}{l}\text { Standardized } \\
\text { Coefficients }\end{array}$ & & \multirow{2}{*}{ Sig. } \\
\cline { 2 - 5 } & $\mathrm{B}$ & Std. Error & Beta & & \\
\hline (Constant) & 1.980 & .689 & & 5.064 & .000 \\
\hline SERVICE & .751 & .355 & .475 & 2.488 & .051 \\
\hline AMENITIES & .288 & .348 & .188 & 3.563 & .041 \\
\hline
\end{tabular}

a. Dependent Variable: CUSTOMER_SAISFACTION

Source: Data processed by researchers (2021)

The equation of the resulting Multiple linear regression is: $\mathrm{Y}=\mathrm{b} 0+\mathrm{b} 1 \mathrm{X} 1+\mathrm{b} 2 \mathrm{X} 2+\mathrm{e} \mathrm{Y}=1,980+0.751$ $+0.288$

From the linear regression model it can be seen that:

1. A constant of 1,980 means that if the value of service (X1) and facilities (X2) is 0.751 and 0.288 , then customer satisfaction is worth 1.980

2. The service variable regression coefficient (X1) is 0.751 , meaning that if the other independent variables remain and the service increases by 1 unit, customer satisfaction (Y) will increase by 0.751 . The coefficient is positive, meaning that there is a unidirectional relationship between services and facilities. The better the service, the more customer satisfaction increases. The facility variable regression coefficient (X2) is 0.288 , which means that it has a positive relationship (reciprocal), if other independent variables have a fixed value and the facility has increased by 1 unit, customer satisfaction (Y) will increase by 0.288 . The coefficient is positive between facilities and customer satisfaction, if the facility increases, customer satisfaction will increase.

Results of Correlation Testing and Coefficient of Determination (R2)

Table 6. Results of Correlation Testing and Determination Coefficient (R2

\begin{tabular}{lllll}
\multicolumn{5}{c}{ Model Summary } \\
\hline Model & $\mathrm{R}$ & R Square & $\begin{array}{l}\text { Adjusted } \\
\text { Square }\end{array}$ & $\begin{array}{c}\text { R Std. Error of } \\
\text { the Estimate }\end{array}$ \\
\hline 1 & $.582^{\mathrm{a}}$ & .783 & .787 & .91769
\end{tabular}

a. Predictors: (Constant), AMENITIES _ SERVICE

Source: Data processed by researchers (2021) 
From the table 4.10 above, the $\mathrm{R}$ value of 0.582 can be obtained. This indicates that there is a weak relationship between service and facilities on customer satisfaction. As for the R Square, it was obtained that it was 0.327 or (32.7\%). This shows that the percentage of the contribution of the influence of the independent variables (services and facilities) to the dependent variable (customer satisfaction) is $32.7 \%$, or the variation of the independent variables used in the model (services and facilities) is able to explain $32.7 \%$ of the variation in the dependent variable (customer satisfaction)., while the remaining $67.3 \%$ is influenced or explained by other variables not included in this research model.

\section{Hypothesis test}

Partial Test Result (t)

Table 7. Variable: CUSTOMER_SAISFACTION

\begin{tabular}{cccccc}
\multicolumn{7}{c}{ Coefficients $^{\mathrm{a}}$} \\
& $\begin{array}{c}\text { Unstandardized } \\
\text { Coefficients }\end{array}$ & $\begin{array}{c}\text { Standardized } \\
\text { Coefficients }\end{array}$ & $\mathrm{t}$ & Sig. \\
\cline { 2 - 5 } & $\mathrm{B}$ & Std. Error & Beta & & \\
\hline (Constant) & 1.920 & .699 & & 5.581 & .000 \\
\hline SERVICE & .751 & .344 & .452 & 2.326 & .037 \\
\hline FACILITIES & .259 & .339 & .158 & 3.255 & .021 \\
\hline
\end{tabular}

Source: Data processed by researchers (2021)

Based on table 7 the effect between the independent variable on the dependent variable partially is as follows: The first hypothesis in this study is that service has a significant effect on customer satisfaction. , 05 or $0.037<\alpha 0.05$ then the hypothesis (H1) is accepted. The service variable has thitu $n g$, namely 2.326 with ttabel1.920. So, sothitu ng ttabel it can be concluded that service has a contribution to customer satisfaction. A positive $t$ value means that the service variable has a direct relationship with customer satisfaction. The second hypothesis in this study is that facilities have a significant effect on customer satisfaction. Based on the table above, the resulting significant value is 0.021 , which means that the significant value is smaller than the probability value $\alpha 0.05$ or $0.021<\alpha 0.05$, then the hypothesis (H2) is accepted. The facility variable has $t$-hitu $n$ g that is 3,255 with $t$-tabel1,920 so $t$-hitung $>t$-tabel can be concluded that the facility has a contribution to customer satisfaction. Positive $t$ value means that the facility variable has a reciprocal relationship with customer satisfaction. So it can be concluded that the facility has a significant effect on customer satisfaction.

\section{Simultaneous Test $(\mathbf{F})$}

Table 8 Simultaneous Test Results (F)

\begin{tabular}{lllllll}
\multicolumn{7}{c}{ ANOVA $^{\mathrm{a}}$} \\
\hline Model & $\begin{array}{c}\text { Sum of } \\
\text { Squares }\end{array}$ & Df & $\begin{array}{c}\text { Mean } \\
\text { Square }\end{array}$ & F & Sig. \\
\hline & Regression & 2.157 & 2 & 1.078 & 53.321 & $.040^{\mathrm{b}}$ \\
\hline 1 & Residual & 31.503 & 97 & .325 & & \\
\hline & Total & 33.660 & 99 & & & \\
\hline
\end{tabular}

a. Dependent Variable: CUSTOMER_SAISFACTION

b. Predictors: (Constant), AMENITIES _ SERVICE

Source: Data processed by researchers (2021)

Based on the table above, the ANOVA section shows that the p-value is sig. $0.040<0.05$ and $\mathrm{F}$ count $=53$, $321>\mathrm{F}$ table $=3,18$ (F table seen from table $\mathrm{F}$ with $\mathrm{dk}$ denominator value $=54-2-1=51$ and dk numerator $=2$ at $5 \%$ significance level). While the correlation is $\mathrm{R}=0.582$, which means that there is a very strong 
correlation between Service Quality and Facilities and Customer Satisfaction. The decision of the simultaneous hypothesis test is: H0 is rejected and Ha is accepted, it means that Service Quality and Facilities have an effect on Customer Satisfaction. The simultaneous influence was $78.30 \%$ ( $\mathrm{R} 2=0.783$ ). While the remaining $21,70 \%$ is influenced by other factors not examined. To test the hypothesis partially, for the Service variable (X1) $p$ value $0.000<0.05$ or $t$ count $4,766>t_{\text {table }} 2,004$. Then the Facility variable (X2) $p$-value $0.010<0.05$ or $t$ count $4,801>t_{\text {table }} 2,004$. Then the decision from the partial hypothesis test is:

1) The first hypothesis: $\mathrm{H}_{0}$ is rejected and $\mathrm{H}_{\mathrm{a}}$ is accepted, meaning that Service Quality (X1) has a partial effect on Customer Satisfaction (Y)

2) The second hypothesis: $\mathrm{H}_{0}$ is rejected and $\mathrm{H}_{\mathrm{a}}$ accepted, meaning Facilities (X2) partial effect on Customer Satisfaction (Y).

Based on the results of the above calculations, the revised path coefficient value of the effect of Service Quality (X1) Facilities (X2) on Customer Satisfaction (Y) is as follows:

The influence of Service Quality (X1) Facilities (X2) on Customer Satisfaction (Y) is as follows:

Table 9. Path Calculation Results

\begin{tabular}{ll}
\hline Variabel & $\begin{array}{l}\text { Koefisien } \\
\text { Jalur }\end{array}$ \\
\hline Service Quality $\left(\mathrm{X}_{1}\right)$ & 0,460 \\
\hline Amenities $\left(\mathrm{X}_{2}\right)$ & 0,464 \\
\hline
\end{tabular}

Source: Data processed by researchers (2021)

The table above illustrates the results of the path calculation, that variable X1 has a path coefficient of 0.460 , Variable X2 has a path coefficient of 0.464 , These results are illustrated in the path equation as below.

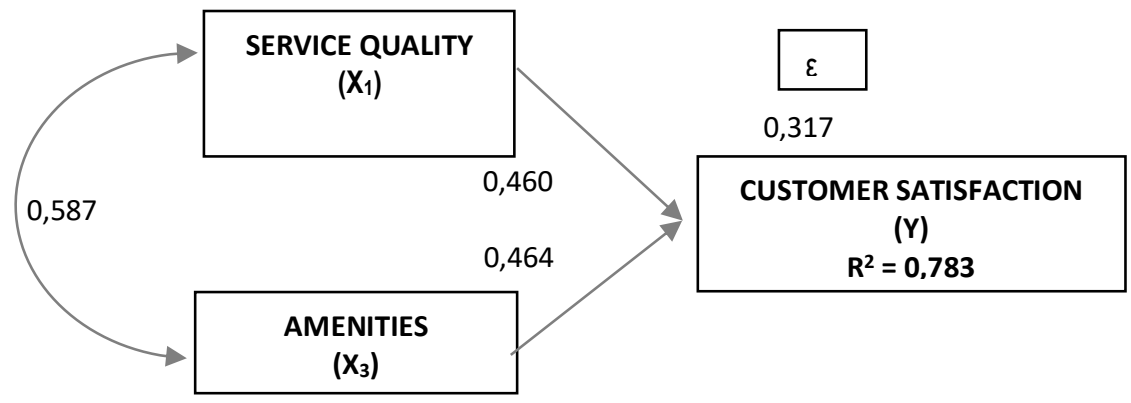

Figure 3: Path Analysis

Source: Results of SPSS Path analysis (2021)

The path equation can be described as follows:

$\mathrm{Y}=0.460 \mathrm{X} 1+0.464 \mathrm{X} 2+\varepsilon$

Where:

$\mathrm{Y}=$ Customer Satisfaction

$\mathrm{X} 1=$ Quality of Service

$\mathrm{X}_{2}=$ Amenities 
The directeffectwith path analysis can be calculated through the results of the effect of regression calculations (X1 and X2) then squared (a2). While the indirect effect on Y can be calculated Service Quality (X1) on Customer Satisfaction (Y) through Facilities (X2) and Facilities (X2) on Customer Satisfaction (Y) through Service Quality (X1). From the data above, it can be seen that the directeffectand indirecteffect by means of path analysis of the independent variable on $\mathrm{Y}$ as the dependent variable. For more details, the calculation of the effect of the above variables can be seen in the calculation table below:

1) The influence of Service Quality (X1) on Customer Satisfaction (Y) is:

Table 10. Effect of Service Quality on Customer Satisfaction

\begin{tabular}{llll}
\hline Variable & Path analysis interpretation & Calculation Process & $\begin{array}{l}\text { Magnitude } \\
\text { Influence }\end{array}$ \\
\hline $\mathrm{X}_{1}$ & Direct influence to Y & $0.460 \times 0.460$ & 0.212 \\
\hline & $\begin{array}{l}\text { Indirect influence through X2 } \\
\text { to Y }\end{array}$ & $0.460 \times 0.788 \times 0.464$ & 0.168 \\
\hline Total & & $\mathbf{0 , 3 8 0}$ \\
\hline
\end{tabular}

Source: Data processed by researchers (2021)

From the table 10, it can be seen that the direct effect of service on customer satisfaction is 0.212 through the service quality of 0.168 and overall is 0.380 .

Table 11. Total Effects, Direct and Indirect Effects

\begin{tabular}{|c|c|c|c|c|}
\hline \multirow{3}{*}{ Variabel } & \multicolumn{4}{|c|}{ Customer Satisfaction (Y) } \\
\hline & \multirow{2}{*}{$\begin{array}{c}\text { Direct } \\
\text { Influence }\end{array}$} & \multicolumn{2}{|c|}{ Indirect Influence } & \multirow{2}{*}{ Total Effect } \\
\hline & & $\mathrm{X}_{1}$ & $\mathrm{X}_{2}$ & \\
\hline $\begin{array}{ll}\text { Service } & \text { Quality } \\
\left(X_{1}\right) & \end{array}$ & $21,20 \%$ & - & $16,8 \%$ & $38,00 \%$ \\
\hline Amenities $\left(\mathrm{X}_{2}\right)$ & $21,50 \%$ & $\begin{array}{l}18,8 \\
\%\end{array}$ & - & $40,30 \%$ \\
\hline Total & $42,70 \%$ & $\begin{array}{l}18,8 \\
\%\end{array}$ & $16,8 \%$ & $78,30 \%$ \\
\hline
\end{tabular}

Source: Data processed by researchers (2021)

Based on the table above, it can be seen that the Service Quality variable (X1) has a direct effect of $21.20 \%$, the indirect effect through its relationship with Service (X2) is $16.80 \%$, so that the total effect is $38.00 \%$. Facility variable (X2) has a direct effect of $21.50 \%$, an indirect effect through its relationship with Service Quality (X1) of $16.80 \%$, so that the total effect is $40.30 \%$. So that the overall effect of Service Quality (X1) and Facilities (X2) on Customer Satisfaction (Y) is 78.30\%. Meanwhile, other factors that are not researched and also affect Customer Satisfaction at PT. Islamic People's Finance Bank Karimah Bekasi's assets are shown by the value of $\mathrm{Py} \varepsilon=0.317$ or $31.70 \%$. Calculated as follows: $\varepsilon=1-\mathrm{R} 2(0683)=0.317$ or 31.70

\section{CONCLUSION AND RECOMMENDATION}

Based on the results of research and discussion on the effect of service quality and facilities on customer satisfaction / users of the Commuter Line train, the authors can draw the following conclusions. Service quality has a positive and significant effect on user satisfaction of KRL Commuter Line. Facilities have a positive and significant effect on user satisfaction of KRL 
Commuter Line. Service quality and facilities together have a positive and significant effect on customer satisfaction. Customer satisfaction is a factor that can influence customers whether they continue to use rail mass transportation or switch to other transportation, even private transportation, which will have an impact on the smoothness, comfort and health of city residents. For this reason, a more aggressive and fast handling is needed and the need for cooperation between the five regional heads, namely the Jabodetabek regional government and the PT KAI Commuter Line. From the results of the analysis of public perceptions or train users both on service quality and perceptions of the Commuter Line train facilities is very small, namely not more than $40 \%$ of the user satisfaction index. This is a warning for PT KAI to immediately improve the facilities located both on the train itself and inside the station for the convenience and safety of users. For further researchers, it can expand the research variables that can affect customer satisfaction. In this study, only $78.30 \%$ of customer satisfaction can be explained by the variable service quality and facilities, which means that around $21.70 \%$ is influenced by other factors not examined in this study.

\section{REFERENCES}

Angelova, B., \& Zekiri, J. (2011). Measuring customer satisfaction with service quality using American Customer Satisfaction Model (ACSI Model). International Journal of Academic Research in Business \& Social Sciences, 1(3), 232-258. https:// doi.org/10.6007/ijarbss.v1i2.35

Agarwal, I., \& Gowda,K.R. (2020). The Effect of Airline Service Quality on Customer Satisfaction and Loyalty in India. Materials Today: Proceedings, 37, 1341-48.

Chang, Y. H., \& Yeh, C. H. (2017). Corporate social responsibility and customer loyalty in intercity bus services. Transport Policy, 59, 38-45. http://dx.doi.org/10.1016/j.tranpol.2017.07.001

Chen, K.K., Chang, C.T., \& Lai, C.S. (2009). Service quality gaps of business customers in the shipping industry. Transportation Research Part E: Logistics and Transportation Review, 45(1), 222-237.

Chauhan, V., Gupta, A. \& Parida, M. (2021). Demystifying Service Quality of Multimodal Transportation Hub ( MMTH ) through Measuring Users Satisfaction of Public Transport. Transport Policy, 102, 47-60.

Eren, S., Eren, M., Ayas, N., \& Hacioglu, G. (2013). The effect of service orientation on financial performance: The mediating role of job satisfaction and customer satisfaction. Procedia-Social and Behavioral Sciences, 99, 665-672. doi:10.1016/j. sbspro.2013.10.537

Ghosh, P., Joshi, J. P., Satyawadi, R., Mukherjee, U., \& Ranjan, R. (2011). Evaluating effectiveness of a training programme with trainee reaction. Industrial and Commercial Training, 43(4), 247-255.

Jung, N.Y., \&b Seock, Y.K. (2017). Efect of service recovery on customers' perceived justice, satisfaction, and word-of-mouth intentions on online shopping websites. Journal of Retailing and Consumer Services. 37(1): 23-30.

Kassem, H., Alhafi Alotaibi, B., Muddassir, M., \& Herab, A. (2021). Factors influencing farmers' satisfaction with the quality of agricultural extension services. Evaluation and Program Planning, 85,101912. https://doi.org/ 10.1016/j.evalprogplan.2021.101912

Kim, J.Y., Bartholomew, K., \& Ewing, R. (2020). Another One Rides the Bus ? The Connections between Bus Stop Amenities, Bus Ridership , and ADA Paratransit Demand. Transportation Research Part A, 135, 280-88.

Lai, W.T., \& Chen, C.F. (2011). Behavioral Intentions of Public Transit Passengers - The Roles of Service Quality, Perceived Value , Satisfaction and Involvement. Transport Policy, 18(2), 318-25.

Le-Klähn, D.T., Hall, C. M., \& Gerike, R. (2014). Analysis of visitor satisfaction with public transport in Munich. Journal of Public Transportation, 17(3), 68-85.

Li, F., Lu, H., Hou, M., Cui, K., Darband.M. (2021). Customer Satisfaction with Bank Services: The Role of Cloud Services, Security, e-Learning and Service Quality. Technology in Society, 64, 101487. 
Mansur, S., Saragih, N., Susilawati, S., Udud, Y., \& Endri, E. (2021). Consumer Brand Engagement and Brand Communications on Destination Brand Equity Maritine Tourism in Indonesia. Journal of Environmental Management and Tourism, 14(4), 1032-1042.

Mustaffa, W. S. W., Bing, K. W., Rahman, R. A., \& Wahid, H. A. (2016). Examining the effect of service personal values on emotional satisfaction with service experience among international students in Malaysian public universities. Procedia Economics and Finance, 35, 713-721.

Pahala, Y., Widodo, S., Kadarwati., Azhari, M., Muliyati., Lestari, N.I., Madjid, S.A., Sidjabat, S., Limakrisna, N., \& Endri, E. (2021). The effects of service operation engineering and green marketing on consumer buying interest. Uncertain Supply Chain Management, 9(3), 603-608.

Parasuraman, A. (2010). Service productivity, quality and innovation. International Journal of Quality and Service Sciences, 2(3), 277-286. DOI:10.1108/17566691011090026

Permana, A., Aima, M.H., Ariyanto, E., Nurmahdi, A., Sutawidjaya, A.H., \& Endri, E. (2021). The effect of compensation and career development on lecturer job satisfaction. Accounting, 7(6), 1287-1292. doi: 10.5267/j.ac.2021.4.011

Rachman, F.F., Nooraeni, R., \& Yuliana, L. (2021). Public Opinion of Transportation Integrated (Jak Lingko), in DKI Jakarta, Indonesia.Procedia Computer Science, 179, 696-703.

Ranaweera, C., \& Prabhu, J. (2003). The influence of satisfaction, trust and switching barriers on customer retention in a continuous purchasing setting", International Journal of Service Industry Management, 14(4), 374-395.

Rita, P., Oliveira, T., \& Farisa, A. (2019). The impact of e-service quality and customer satisfaction on customer behavior in online shopping. Heliyon, 5(10), e02690. https://doi.org/10.1016/j.heliyon.2019.e02690

Santos, G., Marques, C.S., Justino, E., \& Mendes, L. (2020). Understanding Social Responsibility's Influence on Service Quality and Student Satisfaction in Higher Education. Journal of Cleaner Production, 256, 120597.

Saw, Y,Q., Dissanayake, D., Ali, F.m \& Bentotage, T. (2020). Passenger Satisfaction towards Metro Infrastructures, Facilities and Services. Transportation Research Procedia, 48, 3980-95.

Shokouhyar, S., Shokoohyar, S.m \& Safari, S. (2020). Research on the Influence of After-Sales Service Quality Factors on Customer Satisfaction. Journal of Retailing and Consumer Services 56, 102139.

Son, J. H., Kim, J.H., \& Kim, G.J. (2021). Does Employee Satisfaction Influence Customer Satisfaction? Assessing Coffee Shops through the Service Profit Chain Model. International Journal of Hospitality Management, 94, 102866.

Tse, D. K., Nicosia, F. M., \& Wilton, P. C. (1990). Consumer satisfaction as a process. Psychology and Marketing, 7(3), 177-193. doi:10.1002/mar.4220070304

Wang, T., Wang, Y., Zhao, X., \& Fu, X. (2018). Spatial distribution pattern of the customer count and satisfaction of commercial facilities based on social network review data in Beijing, China. Computers, Environment and Urban Systems 71, 88-97

Waseso, S. (2013). The Influence of Perceived Service Quality, Mooring Factor, and Relationship Quality on Customer Satisfaction and Loyalty. Procedia - Social and Behavioral Sciences 81(28), 306-10.

$\mathrm{Xu}, \mathrm{X}$. (2021). What Are Customers Commenting on, and How Is Their Satisfaction Affected? Examining Online Reviews in the on-Demand Food Service Context. Decision Support Systems, 142, 113467. 